\title{
KEANEKARAGAMAN SERANGGA DI KAWASAN IUPHHK-HTI PT. MUARA SUNGAI LANDAK KABUPATEN MEMPAWAH KALIMANTAN BARAT
}

\author{
Fredicus Ricco ${ }^{1}$, Kustiati ${ }^{1}$, Riyandi ${ }^{1}$ \\ ${ }^{1}$ Program Studi Biologi, Fakultas MIPA, Universitas Tanjungpura, \\ Jl. Prof. Dr. H. Hadari Nawawi, Pontianak, \\ email korespondensi : fredicus.ricco@gmail.com
}

\begin{abstract}
Insect is a dominant group of animals on earth with the most common number of species and individuals compared to other animal groups. Research about insect diversity in the forest area of IUPHHK-HTI PT. Muara Sungai Landak in swamp peat forest should be done to know its role. The research was aimed to determine the species of insects and to know the effect of environmental factors to insects in the area of PT. Muara Sungai Landak. Insects collected from five different age groups of plants with trapping methods using pit fall trap, yellow pan trap, and light trap. Insects found in the area of PT. Muara Sungai Landak counted as many as to 282 individuals consisting of 18 species, 15 families, and 6 orders. The most widely found number of individuals was the species of Condylostylus longicornis. The highest diversity value was found in the two-year plant age group with a diversity value of $\mathrm{H}^{\prime}=1,69654$, while the lowest diversity value was found in the three-year plant age group with the value $\mathrm{H}^{\prime}=1,20751$.
\end{abstract}

Keywords: Insect, diversity, PT. Muara Sungai Landak, potential insect

\section{PENDAHULUAN}

Serangga atau insekta merupakan kelas dalam Avertebrata yang dominan di permukaan bumi. Serangga juga sering disebut Heksapoda yang berarti mempunyai enam tungkai (Arthur et al., 2004). Serangga memiliki jenis dengan jumlah yang paling banyak dibandingkan dengan kelompok hewan lainnya. Sebanyak kurang lebih 1.413.000 jenis telah berhasil diidentifikasi dan dikenal, lebih dari 7.000 jenis baru ditemukan hampir setiap tahunnya (Borror et al., 1996).

Beberapa anggota dari serangga memiliki peranan yang menguntungkan maupun merugikan dalam kehidupan. Peran merugikan serangga di bidang pertanian dan kehidupan adalah sebagai hama tumbuhan budidaya, sebagai vektor pembawa penyakit pada tanaman, dan sebagai penyebab penyakit pada manusia. Peran positif serangga adalah sebagai polinator atau penyerbuk, sebagai dekomposer atau pengurai, sebagai predator atau parasitoid (musuh alami), sebagai bioindikator lingkungan, sebagai penghasil bahan-bahan yang bermanfaat dalam bidang kesehatan. Menurut Meilin \& Nasamsir (2016) serangga hidup dalam tanah, darat, udara maupun air tawar sebagai parasit pada tubuh makhluk hidup lain, akan tetapi serangga jarang hidup dalam air asin (laut). Faktor lingkungan merupakan faktor yang berhubungan dengan tempat hidup serangga. Keanekaragaman dan kelimpahan serangga secara umum akan ditentukan pula oleh faktor lingkungan. Setiap jenis serangga mempunyai kesesuaian terhadap lingkungan tertentu. Oleh karena itu, faktor fisik lingkungan, terutama suhu dan kelembaban sangat berpengerauh terhadap keberadaan serangga. Kondisi lingkungan yang berbeda menyebabkan kelimpahan serangga tiap tipe habitat berbeda. Suhu berpengaruh terhadap aktivitas serangga, penyebaran geografis dan lokal, serta perkembangan. Kelembaban mempengaruhi penguapan cairan tubuh serangga dan pemilihan habitat yang cocok (Haneda et al., 2013).

Menurut hasil penelitian Haneda et al., (2013), suhu pada kisaran $29-31^{\circ} \mathrm{C}$ merupakan suhu yang optimal untuk perkembangan serangga pada umumnya. Sedangkan pada hasil pengukuran kelembaban didapatkan hasil yang berbanding terbalik dengan keadaan suhu lingkungan pada lokasi pengamatan dengan kisaran $70-72 \%$ yang merupakan kisaran kelembaban optimal serangga. Faktor lingkungan (suhu dan kelembaban) akan terlihat pengaruhnya terhadap kelimpahan dan keanekaragaman serangga jika pengambilan sampel dilakukan dengan waktu yang lama dan pada musim yang berbeda. 
Jenis Acacia sp., adalah salah satu jenis tanaman pokok yang dikembangkan pada Hutan Tanaman Industri (HTI) untuk bahan baku pulp dan kertas. Permasalahan pada jenis tanaman tersebut adalah produktivitasnya masih rendah serta daurnya masih panjang untuk kesinambungan suplai kayu terhadap industri kertas. Perusahaan HTI menurunkan daur tebang jenis tanaman akasia yaitu dari umur 6-7 tahun menjadi umur 4-5 tahun (National Research Council, 1983 dalam Krisnawati et al., 2011). Untuk mengetahui dampak dari penurunan daur tebang pohon tersebut menurut (Suhartati et al., 2014) perlu dilakukan kajian terhadap produksi dan kualitas kayu serta kondisi ekologis dan sosial pada kawasan HTI tersebut.

Perusahaan Muara Sungai Landak merupakan salah satu perusahaan HTI yang menerapkan penurunan

daur tebang pohon untuk kesinambungan suplai kayu. Kawasan HTI PT. Muara Sungai Landak memiliki kondisi ekologis berupa lahan basah gambut tropis dengan substrat organik yang bersifat asam dan miskin hara. Kajian ekologis baik faktor biotik maupun abiotik yang dapat mempengaruhi produktivitas pada kawasan tersebut belum pernah dilakukan. Salah satu faktor biotik yang penting dalam suatu kawasan tanaman industri adalah keberadaan serangga. Keberadaan serangga dapat menguntungkan ataupun merugikan. Serangga yang menguntungkan meliputi serangga yang memiliki peran sebagai polinator, dekomposer, atau musuh alami (predator dan parasitoid), sedangkan serangga yang merugikan meliputi serangga hama dan serangga vektor pembawa penyakit tanaman. Kajian terhadap keberadaan dan keragaman jenis serangga pada kawasan PT. Muara Sungai Landak perlu dilakukan sebagai upaya untuk mengetahui serangga yang mengutungkan ataupun yang merugikan. Hal ini perlu diketahui untuk dapat melakukan monitoring terhadap populasi serangga yang berpotensi sebagai hama atau sebaliknya.

Tujuan penelitian ini adalah untuk mengetahui keanekaragaman jenis serangga yang terdapat di kawasan PT. Muara Sungai Landak berdasarkan kelompok umur tanaman.

\section{BAHAN DAN METODE}

\section{Waktu dan Tempat}

Penelitian dilakukan selama tujuh bulan mulai dari bulan November 2018 hingga Mei 2019 yang meliputi persiapan alat, pengambilan sampel, identifikasi dan analisis data. Pengambilan sampel dilaksanakan di area PT. Muara Sungai Landak Kabupaten Mempawah. Identifikasi sampel dilakukan dilakukan di Laboratorium Zoologi Jurusan Biologi Fakultas Matematika dan Ilmu Pengetahuan Alam Universitas Tanjungpura.

\section{Deskripsi Lokasi}

Lokasi PT. Muara Sungai Landak merupakan area bekas HPH PT. Aria Jaya dan berada pada satu hamparan di batas antara Kecamatan Segedong dan Kecamatan Jongkat Kabupaten Mempawah dengan titik koordinat $109^{0} 14^{\prime} 35^{\prime \prime}-109^{0} 211^{\prime} 50^{\prime \prime}$ BT dan $00^{\circ} 15^{\prime} 00^{\prime}-00^{0} 14^{\prime} 35^{\prime \prime}$ LU. Area PT. Muara Sungai Landak merupakan areal hutan tanaman industri (HTI) dengan luas area $13.000 \mathrm{Ha}$ (Gambar 1)

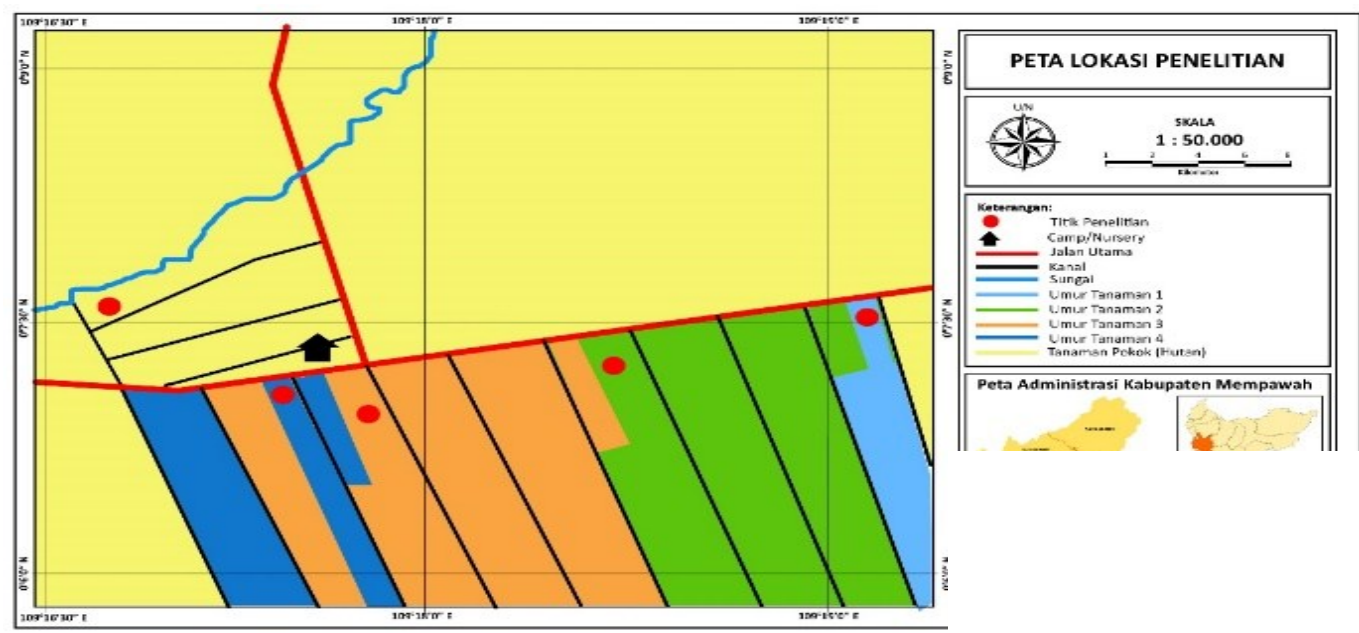

Gambar 1. Peta Stasiun Penelitian PT. Muara Sungai Landak (PT. Muara Sungai Landak, 2018) 


\section{Alat dan Bahan}

Alat dan bahan yang digunakan dalam penelitian meliputi pinset, botol koleksi, termohigrometer, kamera, alat tulis, senter, tali rapia, meteran gulung, gunting, piring plastik/baskom (wadah plastik berwarna kuning), mikroskop, buku identifikasi (Borror et al., 1996) dan (Suin, 1997). Bahan yang digunakan dalam penelitian ini antara lain aquades, alkohol $70 \%$, formalin $4 \%$, tisu, dan kertas.

\section{Penentuan Stasiun}

Lokasi penelitian dibagi menjadi lima stasiun pengamatan yang terdiri dari empat umur tanaman yang berbeda dan satu kawasan tanaman pokok (hutan), yaitu umur satu tahun (stasiun I), umur dua tahun (stasiun II), umur tiga tahun (stasiun III), umur empat tahun (stasiun IV), dan tanaman pokok ( stasiun V).

\section{Pengambilan dan Identifikasi Sampel Serangga}

Metode yang digunakan dalam penelitian adalah metode purposive sampling dengan lima stasiun pengamatan. Pengambilan sampel pada setiap stasiun dilakukan tiga kali ulangan waktu dengan selang dua minggu untuk setiap pengambilan. Pengambilan sampel serangga menggunakan tiga jenis perangkap, yakni yellow pan trap, pitfall trap, dan light trap masing-masing sebanyak tiga perangkap secara acak pada plot pengamatan berukuruan $2 \times 2$ meter setiap stasiun. Perangkap yellow pan trap dan pitfall trap dipasang selama 12 jam dari jam 06.00 hingga 18.00 WIB, sedangkan. light trap digantungkan pada tiang dengan ketinggian 1-1,5 meter dari jam 18:00 hingga jam 06:00 keesokan harinya. Sampel serangga yang terperangkap selanjutnya dimasukan ke dalam botol koleksi dan diberi label sesuai dengan jenis perangkap untuk masing-masing stasiun. Sampel serangga kemudian dibawa ke laboratorium untuk dilakukan determinasi dengan menggunakan bukubuku identifikasi yang tersedia (Borror et al., 1996).

\section{Pengukuran Faktor Lingkungan}

Data faktor lingkungan yang diukur dalam penelitian adalah suhu dan kelembaban udara menggunakan termohigrometer. Termohigrometer diletakkan di atas permukaan tanah pada pagi dan sore hari saat pemasangan perangkap dan pengambilan perangkap. Pembacaan dan pen- catatan skala pada termohigrometer dilakukan \pm 5 menit setelah peletakan.

\section{Analisis Data}

Data jumlah individu dan jenis serangga yang diperoleh dikelompokkan berdasarkan stasiun pengamatan dan perangkap. Selanjutnya, data jumlah individu setiap jenis dianalisis secara inferensial untuk menentukan nilai keanekaragaman jenis dan nilai kemerataan pada masingmasing stasiun pengamatan dengan rumus sebagai berikut:

Indeks keanekaragaman Shannon-Wiener $\left(\mathrm{H}^{\prime}\right)$ :

$$
H^{\prime}=\sum_{i=1}^{n} p i \ln p i
$$

Indeks Dominansi:

$$
C=\sum_{i=1}^{n}(p i)^{2}
$$

Indeks Kemerataan Eveness (E):

$$
E=\frac{H^{\prime}}{\log S}
$$

Keterangan:

$\mathrm{H}^{\prime}=$ Indeks keanekaragaman

$\mathrm{C}=$ Indeks dominansi

$\mathrm{E}=$ Indeks kemerataan

pi $=$ kelimpahan relatif $(n i / \mathrm{N})$

$\mathrm{ni}=$ jumlah individu suatu jenis

$\mathrm{N}=$ jumlah total individu seluruh jenis

$\mathrm{S}=$ jumlah jenis setiap stasiun

(Suin, 1997)

Kriteria untuk indeks keanekaragaman menurut Krebs (1989) sebagai berikut:

$$
\begin{array}{ll}
\mathrm{H}>3 & \text { (Tinggi) } \\
\mathrm{H}<\mathrm{H}<3 & \text { (Sedang) } \\
\mathrm{H}<1 & \text { (Rendah) }
\end{array}
$$

Kriteria tingkat kemerataan menurut Odum (1993):

$$
\begin{array}{ll}
\mathrm{E}<0.4 & \text { (rendah) } \\
\mathrm{E}=0.4-0.6 & \text { (sedang) } \\
\mathrm{E}>0.6 & \text { (tinggi) }
\end{array}
$$

\section{HASIL DAN PEMBAHASAN}

\section{Komposisi Jenis Serangga di Kawasan PT. Muara Sungai Landak}

Serangga yang ditemukan di kawasan PT. Muara Sungai Landak Kabupaten Mempawah dalam 
penelitian berjumlah 282 individu yang tersusun oleh 18 jenis, 15 famili, dan enam ordo, yaitu Blattoidea, Coleoptera, Diptera, Hymonoptera, Isoptera, dan Orthoptera. Kelimpahan atau jumlah serangga paling sedikit ditemukan pada stasiun dengan tanaman umur 3 tahun. Jenis serangga yang ditemukan pada semua stasiun pengamatan dengan banyak individu adalah Condylostylus longicornis dan Macrotermes gilvus (Tabel 1).

Condylostylus longicornis atau lalat kaki panjang merupakan anggota famili Dolichopodidae, famili terbesar ordo Diptera, yang dikenal sebagai pemangsa (predator) baik pada stadium dewasa maupun larva. Lalat dewasa memangsa kutu daun, wereng, thrips, kutu putih, dan tungau yang menjadi hama pada tanaman. Larva hidup di perairan, berlumpur, atau tempat-tempat lembab (Cicero et al., 2017, Daly et al., 1981). Lokasi penelitian yang rupa perkebunan di lahan gambut dengan kanal-kanal di sekitarnya menyediakan tempat bagi kelangsungan hidup serangga ini se- hingga dapat ditemukan pada semua stasiun pengamatan.

Macrotermes gilvus atau rayap tanah (Isoptera: Termitidae) dikenal sebagai hama pada berbagai tanaman perkebunan. Serangga ini memakan kayu (Xylopagus) dan hidup di dalam tanah yang banyak mengandung bahan lignoselulosa pada kayu yang telah mati (Nandika et al., 2003). Meskipun rayap tanah belum pernah dilaporkan sebagai hama pada tanamana akasia, namun serangan rayap tanah pada perkebunan jika tidak segera dilakukan pengendalian dapat menimbulkan kerugian secara ekonomi dengan menurunkan kualitas dan kuantitas produksi (Sayuthi, 2012). Keberadaan rayap ini pada semua stasiun pengamatan di kawasan perkebunan PT. Muara Sungai Landak mengindikasikan bahwa rayap ini perlu mendapat perhatian. Hal ini karena rayap menyerang bagian tanaman yang berada di bawah permukaan tanah sehingga serangannya tidak dapat diketahui dari awal. Oleh karena itu, monitoring terhadap populasi rayap ini perlu dilakukan secara rutin dan berkala.

Tabel 1 Jumlah individu serangga yang ditemukan di Kawasan PT. Muara Sungai Landak

\begin{tabular}{|c|c|c|c|c|c|c|c|c|}
\hline \multicolumn{3}{|c|}{ Takson Serangga } & \multicolumn{5}{|c|}{$\sum$ Individu per stasiun } & \multirow[t]{2}{*}{$\sum$} \\
\hline Ordo & Family & Jenis & $\mathrm{I}$ & II & III & IV & $\mathrm{V}$ & \\
\hline Blattodea & Blattelidae & Paracoblatta pennsylvanica & 2 & 1 & 3 & 0 & 0 & 6 \\
\hline \multirow[t]{7}{*}{ Coleoptera } & Cucujidae & Cryptolestes sp. & 1 & 0 & 0 & 0 & 0 & 1 \\
\hline & Lampyridae & Pyropyga sp. & 1 & 0 & 0 & 0 & 0 & 1 \\
\hline & Lycidae & Porrostoma sp. & 0 & 0 & 0 & 15 & 0 & 15 \\
\hline & & Xylobanus insignipennis & 0 & 0 & 0 & 0 & 1 & 1 \\
\hline & Tenebrionidae & Uloma sanguinipes & 0 & 1 & 0 & 0 & 0 & 1 \\
\hline & Scarabaeidae & Anomala flavipennis & 0 & 0 & 0 & 0 & 1 & 1 \\
\hline & & Phyllophaga sp. & 0 & 0 & 0 & 0 & 1 & 1 \\
\hline \multirow[t]{2}{*}{ Diptera } & Dolichopodidae & Condylostylus longicornis & 35 & 17 & 12 & 20 & 18 & 102 \\
\hline & Tachinidae & Anisia flaveola & 0 & 3 & 1 & 0 & 0 & 4 \\
\hline \multirow[t]{5}{*}{ Hymenoptera } & Formicidae & Camponotus festinatus & 0 & 7 & 0 & 18 & 0 & 25 \\
\hline & & Lasius sp. & 8 & 15 & 0 & 0 & 13 & 36 \\
\hline & Ichneumonidae & Enicospilus kikuchii & 0 & 1 & 0 & 0 & 0 & 1 \\
\hline & Pompilidae & Agenioideus cinctellus & 0 & 0 & 1 & 0 & 0 & 1 \\
\hline & Evaniidae & Hyptia narpyoides & 0 & 2 & 0 & 1 & 0 & 3 \\
\hline Isoptera & Termitidae & Marcotermes gilvus & 15 & 22 & 11 & 5 & 18 & 71 \\
\hline \multirow[t]{2}{*}{ Orthoptera } & Tetrigidae & Tetrix subulata & 3 & 0 & 0 & 0 & 0 & 3 \\
\hline & Gryllidae & Acheta domestica & 3 & 0 & 0 & 0 & 6 & 9 \\
\hline$\sum=6$ & 15 & 18 & 69 & 68 & 28 & 59 & 58 & 282 \\
\hline
\end{tabular}


Tabel 2 Jumlah serangga berdasarkan perangkap yang digunakan di Kawasan PT. Muara Sungai Landak

\begin{tabular}{|c|c|c|c|c|c|c|c|}
\hline \multicolumn{5}{|c|}{ Takson Serangga } & \multicolumn{3}{|c|}{$\begin{array}{c}\text { Jumlah Individu per } \\
\text { Perangkap } \\
\end{array}$} \\
\hline Ordo & $\begin{array}{c}\text { Jumlah } \\
\text { Famili }\end{array}$ & Jumlah Jenis & $\begin{array}{l}\text { Jumlah } \\
\text { individu }\end{array}$ & $\begin{array}{c}\text { Persentase } \\
(\%)\end{array}$ & $\begin{array}{c}\text { Yellow } \\
\text { Pan Trap }\end{array}$ & $\begin{array}{c}\text { Pitfall } \\
\text { Trap }\end{array}$ & $\begin{array}{l}\text { Light } \\
\text { Trap }\end{array}$ \\
\hline Blattodea & 1 & 1 & 6 & 2.13 & - & 4 & 2 \\
\hline Coleoptera & 5 & 7 & 21 & 7.45 & - & 1 & 20 \\
\hline Diptera & 2 & 2 & 106 & 37.59 & 99 & - & 7 \\
\hline Hymenoptera & 4 & 5 & 66 & 23.40 & 23 & 13 & 30 \\
\hline Isoptera & 1 & 1 & 71 & 25.18 & - & - & 71 \\
\hline Orthoptera & 2 & 2 & 12 & 4.26 & - & 9 & 3 \\
\hline TOTAL & 15 & 18 & 282 & 100.00 & 122 & 27 & 133 \\
\hline
\end{tabular}

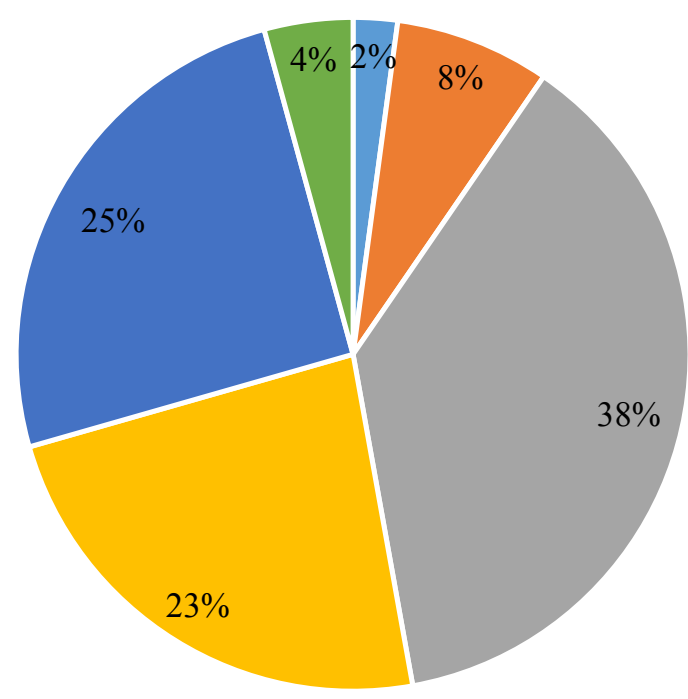

- Blattodea

- Coleoptera

- Diptera

$\square$ Hymenoptera

- Isoptera

- Orthoptera

Gambar 1 Persentase jumlah individu dari ordo serangga yang ditemukan pada kawasan PT. Muara Sungai Landak

Selain Macrotermes gilvus, serangga yang dikenal sebagai hama dan ditemukan pada lokasi penelitian adalah dari ordo Coleoptera, seperti Cryptolestes sp. Cryptolestes sp. dikenal sebagai hama gudang pada biji-bijian (Anggara \& Sudarmaji, 2009) dan dari ordo Orthoptera. Walaupun dalam penelitian ini ditemukan dalam persentase rendah (Tabel 2), namun demikian keberadaannya perlu mendapat perhatian.

Kelompok serangga berguna yang juga ditemukan di kawasan perkebunan tanaman akasia milik PT. Muara Sunga Landak selain dari ordo Diptera, berasal dari ordo Blattodea dan ordo Hymenoptera. Satu jenis serangga dari ordo Blattodea adalah Paracoblatta pennsylvanica atau kecoak kayu. Kecoak kayu biasa hidup pada bahan sisa tanaman yang telah mati. Dalam penelitian ini, kecoak kayu ditemukan pada tiga stasiun pengamatan tanaman umur 1-3 tahun dan tertangkap pada pitfall trap dan light trap (Tabel 2).
Ordo Hymenoptera yang ditemukan di lokasi penelitian ada 66 individu yang berasal dari 5 jenis dan 4 famili yang tertangkap pada ketiga perangkap yang digunakan (Tabel 2). Beberapa jenis anggota Hymenoptera dikenal sebagai parasit atau parasitoid pada organisme serangga atau organisme lain. Dalam penelitian ini, serangga parasit yang ditemukan dalam jumlah lebih banyak dibandingkan jenis lain adalah Camponotus festinatus dan Lasius sp (Tabel 1). Kehadiran serangga berguna, baik sebagai perombak material tanaman yang telah mati, pemangsa (predator) dan parasit atau parasitoid, pada lokasi penelitian ini adalah penting untuk keseimbangan ekosistem.

Jika dilihat dari persentase jumlah individu serangga di Kawasan PT. Muara Sungai Landak, ordo Diptera jumlah paling besar yaitu mencapai $38 \%$ oleh dua jenis dari dua famili. Urutan kedua ditempati ordo Isoptera $25 \%$ namun hanya dari satu jenis. Satu jenis dari ordo Isoptera, yaitu 
Macrotermes gilvus, atau rayap tanah (Tabel 1) dikenal sebagai serangga yang hidup dalam koloni Jumlah individu terbesar ketiga dari ordo Hymenoptera sebanyak 23\% dari 4 famili dan 5 jenis (Tabel 2 dan Gambar 1).

\section{Keanekaragaman Jenis Serangga}

Keanekaragaman jenis merupakan sifat komunitas yang memperlihatkan tingkat keanekaragaman jenis organisme yang ada di dalamnya. Keanekaragaman serangga diketahui dengan menggunakan indeks keanekaragaman ShannonWiener. Indeks keanekaragaman dapat digunakan untuk menyatakan hubungan kelimpahan jenis dalam komunitas (kekayaan jenis) dan kesamaan jenis. Nilai keanekaragaman akan tinggi, jika jumlah individu per jenis merata (Krebs, 1978).

Perbedaan hasil keanekaragaman yang diperoleh diduga disebabkan oleh faktor umur tanaman akasia, keadaan cuaca saat pengambilan sampel, dan keadaan habitat sekitar lahan. Berdasarkan Tabel 4 diketahui bahwa nilai keanekaragaman tertinggi terdapat pada stasiun II 1,69654 dan nilai terendah terdapat pada stasiun III dengan nilai keanekaragaman 1,20751. Hal ini dipengaruhi lokasi pada stasiun dua memiliki rona lingkungan yang lebih beragam seperti di tepi kanal, lokasi semak dan lokasi bekas tumpukan kayu setelah panen. Sementara dominansi yang paling tinggi terdapat pada stasiun III dengan nilai 0,3326 dan didominansi oleh jenis serangga $C$. longicornis dan M. gilvus karena jenis ini merupakan jenis serangga dengan sifat hidup berkoloni. Nilai dominansi yang terendah terdapat pada stasiun II dengan nilai dominansi 0,2232 .

Hasil kemerataan jenis serangga yang diperoleh dimulai dari nilai tertinggi yang terdapat pada stasiun IV dengan nilai 1,9390. Hal ini diduga rona lingkungan pada stasiun IV memiliki umur tanaman yang siap panen dan semak yang sudah mulai tumbuh di sekitar tumbuhan pada lokasi stasiun IV sehingga menyediakan habitat untuk berbagai jenis serangga. Nilai kemerataan yang terendah terdapat pada stasiun I dengan nilai 1,5837 , tingkat keberagaman jenis tumbuhan pada lokasi stasiun I yang sangat rendah, karena pada lokasi ini merupakan lokasi yang baru dibuka dan mengakibatkan rendahnya keanekaragaman tumbuhan yang merupakan habitat bagi serangga.

Tabel 3 Faktor lingkungan dan keanekaragaman serangan kawasan PT. Muara Sunga Landak

\begin{tabular}{lrrrrr}
\hline \multirow{2}{*}{ Keterangan } & \multicolumn{5}{c}{ Umur Tanaman } \\
\cline { 2 - 6 } & \multicolumn{1}{c}{ 1 tahun } & 2 tahun & 3 tahun & 4 tahun & \multicolumn{1}{c}{ Hutan } \\
\hline Indeks Keanekaragaman (H') & 1.43022 & 1.69654 & 1.20751 & 1.35535 & 1.50616 \\
Indeks Dominansi (C') & 0.3326 & 0,2232 & 0,3520 & 0,2800 & 0,2544 \\
Indeks Kemerataan (E') & 1,5837 & 1,7779 & 1,7275 & 1,9390 & 1,7822 \\
Suhu ${ }^{\circ} \mathrm{C}$ & 31.3 & 32.2 & 32.9 & 33.2 & 32.4 \\
Kelembaban (\%) & 57.7 & 54.6 & 50.6 & 56.1 & 58.9 \\
\hline
\end{tabular}

Menurut Speight et al. (1999) bahwa keanekaragaman jenis tumbuhan pada suatu habitat akan mempengaruhi keanekaragaman jenis yang ada di dalamnya. Habitat yang lebih heterogen mampu memberikan "niche" yang lebih banyak, sehingga mampu menopang jenis organisme yang lebih banyak pula. Habitat yang lebih beragam maka keanekaragaman jenis juga lebih tinggi.

Kelimpahan individu dan kekayaan jenis serangga yang diperoleh pada tiap lokasi pengambilan sampel memiliki nilai yang berbeda, perbedaan tersebut dapat disebabkan oleh faktor umur tanaman akasia, keadaan cuaca saat pengambilan sampel dan karakter lokasi setiap stasiun. Fauziah (2015) menjelaskan bahwa hutan alam memiliki keanekaragaman habitat yang lebih bervariasi jika dibandingkan dengan habitat monokultur. Jenis tumbuhan yang terdapat pada hutan alam lebih heterogen. Hal ini menyebabkan keanekaragaman serangga pada hutan alam dapat lebih melimpah dan beragam dibandingkan dengan hutan yang memiliki habitat atau tumbuhan yang monokultur.

\section{DAFTAR PUSTAKA}

Anggara, AW \& Sudarmaji, 2009, Hama Pascapanen Padi dan Pengendaliannya Balai Besar Penelitian Tanaman Padi (ID) Indonesia

Arthur, VE, Rosser, WG \& Neil, S, 2004, Animal Life Encyclopedia. 2sd Edition. Vol-3. Produced by Schlager Group Inc 
Borror, DJ, Triplehorn, CA \& Johson, NF, 1996, Pengenalan Pelajaran Serangga Edisi ke-enam, Gadjah Mada University, Yogyakarta

Cicero, JM, Adair, MM, Adair Jr, RC, Hunter, WB, \& Avery, PB, et al, 2017, Predatory Behavior of Long-Legged Flies (Diptera: Dolichopodidae) and Their Potential Negative Effects on the Parasitoid Biological Control Agent of the Asian Citrus Psyllid (Hemiptera: Liviidae), Florida Entomologist, 100(2): 485-487

Daly, HV, 1981, Introduction to Insect Biology and Diversity: Kagasuka Mc Graw Hill Interntional Book Company

Fauziah, R, 2015, Struktur dan Komposisi Tumbuhan di Hutan Resort Salak 2- Taman Nasional Gunung Halimun Salak (TNGHS). UIN Syarif Hidayatullah, Jakarta

Haneda, FN, Kusuma, C \& Kusuma, FD, 2013, Keanekaragaman Serangga di Ekosistem Mangrove. Jurnal Silvikultur Tropika Vol. 04 No. 01 April 2013, Hal. $42-46$

Krebs, 1978. Ecology. The Experimental Analysis of Distribution and Abundance. $3^{\text {rd }}$ Edition Harper and Row Distribution, New York.

Krebs, 1989. Ecology Methodological, Haper and Row Disribution, New York.

Krisnawati, H, Kallio M \& Kanninen M, 2011, Acacia mangium Willd: Ekologi, Silvikultur, dan Produktivitas, CIFOR, Bogor, Indonesia
Meilin, A \& Nasamsir, 2016, Serangga dan Peranannya dalam Bidang Pertanian dan Kehidupan. Jurnal Media Pertanian, 1 (1) 18-28

Nandika, D, Rismayadi, Y, \& Diba, F, 2003, Rayap, Biologi, dan Pengendaliannya. Surakarta: Muhamadiyah University press

Odum, EP, 1993, Dasar-Dasar Ekologi, Terjemahan Tjahjono Samingan, Edisi Ketiga, Gadjah Mada University Prees, Yogyakarta

Peta RKUPHHK-HTI periode2017/2026 PT. Muara Sungai Landak. Nomor SK. 2837/MenLHKPHPL/UHP/HPL.1/5/2018. Tanggal 7 Mei 2018. Skala 1:50.000

Sayuthi, M, 2012, Rayap Macrotermes gilvus (Hagen) (Isoptera: Termitidae) sebagai Hama Penting pada Tanaman Jarak Pagar (J. curcas) di Kebun Induk Jarak Pagar (KIJP) Pakuwon Sukabumi Jawa Barat, Jurnal Ilmiah Pendidikan Biologi, Biologi Edukasi, 4(1): 56-60

Speight, MR, Hunter, MD, \& Watt, AD, 1999. Ecology of Insect: Concepts and Applications. Blackwell Science Pty Ltd, Oxford

Suin, NM, 1997, Ekologi Hewan Tanah, Buni Aksara, Jakarta

Suhartati, Rahmayanto, Y \& Daeng, Y, 2014, Dampak Penurunan Daur Tanaman HTI Acacia Terhadap Kelestarian Produksi, Ekologis dan Sosial. Eboni, 11 (2) : 103-116 